\title{
PENGUKURAN DAYASAING KLASTER BATIK, KONVEKSI DAN MEBEL DI KABUPATEN SRAGEN
}

\author{
Ma'ruf ${ }^{1}$, Sidiq Permono Nugroho ${ }^{2}$, Andri Veno ${ }^{3}$ \\ Progdi Manajemen dan Bisnis \\ (Fakultas Ekonomi dan Bisnis Universitas Muhammadiyah Surakarta) \\ Jl. A. Yani Pabelan Kartasura Surakarta \\ Email :maruf@ums.ac.id,sp122@ums.ac.id,veno.focus@gmail.com
}

\begin{abstract}
Abstraksi: Percepatan pembangunan ekonomi dan daya saing industri khususnya UMKM telah menjadi perhatian pemerintah pusat maupun daerah. Terdapat berbagai keterbatasan-keterbatasan yang dimiliki oleh UMKM, terutama mengenai rendahnya kualitas SDM, rendahnya kualitas produk UMKM yang disebabkan oleh keterbatasan pengetahuan, peralatan, dan permodalan yang dimiliki oleh para pelaku usaha. Perlu adanya dukungan stakeholder untuk mencari solusi dari permasalahan tersebut. Pengembangan usaha kecil dan menengah merupakan bagian dari pembangunan ekonomi jangka panjang untuk mencapai struktur ekonomi yang seimbang. Tetapi adanya perbedaan potensi sumberdaya, keadaan prasarana dan pasar menyebabkan ketimpangan persebaran lokasi dan perlambatan pertumbuhan. Pembangunan ekonomi daerah diartikan sebagai suatu proses dimana Academic, Business, Community dan Goverment (ABCG) mengelola sumberdaya yang ada dan membentuk pola kemitraan diantara mereka untuk menjalankan roda perekonomian di daerah tersebut. Kabupaten Sragen memiliki 7 Klater UMKM yang beberapa diantaranya merupakan produk unggulan daerah. Penelitian ini untuk mengkaji daya saing 3 klaster UMKM yaitu klaster batik, klaster konveksi dan klaster mebel berdasarkan Kriteria Produk Unggulan Daerah (PUD) menurut Permendagri No. 9 tahun 2014. Tujuan yang diharapkan dari penelitian pengukuran daya saing Klaster Batik, Koveksi Dan Mebel di Kabupaten Sragen adalah kontribusi usaha batik, koveksi dan mebel terhadap PDRB, kemiskinan, dan perkembangan wilayah/lokasi klaster serta memberikan masukan bagi kebijakan yang dilakukan terkait dengan peningkatan daya saing klaster UMKM di Kabupaten Sragen. Penelitian ini memberikan masukan bagi pemerintah Kabupaten Sragen untuk memprioritaskan kebijakan pengembangan daya saing klaster batik pada aspek tenaga kerja, bahan baku, manajemen dan harga. Kemudian untuk klaster konveksi, prioritas kebijakan pengembangan yaitu teknologi, pasar, modal dan basis ekonomi. Klaster batik prioritas kebijakan yang harus dikembangkan yaitu aspek sosial budaya. Analisis data yang digunakan dalam penelitian ini menggunakan Analisis LQ dan shift share, Analystic Hierarchy Process (AHP), dan Analisis Topsis.
\end{abstract}

Kata Kunci: Potensi Ekonomi, Daya Saing, Klaster UMKM.

\begin{abstract}
Economic acceleration and industrial competitiveness, especially SMEs had become the government's attention. There were many limitations of SMEs such as low human resources, product quality, knowledge, equipment and capital. They needed support from stakeholders due to those problems. The development of UMKM aimed to build a long-term and balanced economic structure. There were differences in the potential of human resources, infrastructure and markets lead to widespread inequality of spread and growth. Regional economic development had to be processed by Academic, Business, Community, and Government (ABCG) to manage available resources and establish partnerships. Sragen regency had 7 clusters of SMEs with some of them were the regional superior products. This study examined 3 clusters including batik, convection and meubelair referring to the PERMENDAGRI No. 9, 2014. This study measured the competitiveness of batik, convection and furniture in Sragen regency to PDRB, poverty, regional development. This study provided input for the government in making priority development of SMEs based on aspects of labor, raw materials, management and price. For the convection
\end{abstract}


clusters, policy priorities were directed at technology, markets, capital and economic bases. Policy priorities for batik clusters were socio-cultural aspects. This research used LQ and shift share, AHP, and Topsis analysis.

Keywords: Economic Potential, Competitiveness, SMEs Cluster.

\section{LATAR BELAKANG}

Pemberdayaan usaha mikro kecil dan menengah (UMKM) dalam era globalisasi serta tingginya persaingan mengharuskan UMKM dapat menghadapi setiap tantangan pasar global, seperti meningkatkan perluasan area pemasaran, peningkatan ketrampilan sumber daya manusia dan bahan baku, meningkatkan inovasi produk dan jasa. Hal ini perlu dilakukan untuk meningkatkan nilai jual UMKM itu sendiri, sehingga dapat bersaing dengan produk-produk luar negeri yang semakin membanjiri Indonesia. Mengingat pentingnya UMKM sebagai sektor ekonomi yang dapat menyerap tenaga kerja terbesar di Indonesia. Dalam persaingan usaha domestik dan internasional sebagai dampak dari globalisasi, perdagangan bebas, dan integrasi ekonomi regional yang cepat mengakibatkan semakin meningkatnya persaingan. Persaingan bisnis muncul dari seluruh bagian didunia, yang sama-sama mempunyai peluang terbuka dalam perdagangan bebas, hal ini mengakibatkan besarnya jumlah persaingan dan barang di pasar (Ferrell, et al., 2000).

Perkembangan UMKM di Indonesia senantiasa menghadapi banyak kendala dan berbagai persoalan sehingga menyebabkan lemahnya daya saing terhadap produk impor. Persoalan utama yang dihadapi UMKM, diantaranya keterbatasan infrastruktur dan akses pemerintah yang terkait dengan perizinan dan birokrasi serta tingginya tingkat pungutan. Dengan segala persoalan yang ada, maka perkembangan UMKM menjadi terhambat. Meskipun UMKM bisa dikatakan mampu bertahan dari krisis global namun pada kenyataannya kendala-kendala yang dihadapi sangat banyak dan kompleks. Hal tersebut tidak dipengaruhi oleh krisis global secara langsung, UMKM diharuskan dapat menghadapi persoalan domestik yang tidak kunjung terselesaikan seperti masalah upah buruh, ketenaga kerjaan, pungutan liar, korupsi dan lain-lain.

Untuk menggambarkan tingkat daya saing UMKM, faktor-faktor yang penting untuk diperhatikan yaitu diantaranya, seperti tingkat pendidikan pemilik dan pekerja UMKM, keterampilan dan tingkat kewirausahaan, akses UMKM kepada sumber pembiayaan, akses kepada lembaga pengembangan usaha, faktor-faktor eksternal seperti ke mudahan perijinan dan biaya transaksi, dan lain-lain. Meskipun ukuran daya saing UMKM sangat beragam, identifikasi mengenai daya saing UMKM perlu mencakup tiga karakteristik yaitu potensi, proses, dan kinerja (Tambunan, 2008).

Sejalan dengan kebijakan pembangunan industri kecil dan menengah, baik pada tingkat Nasional ataupun Provinsi Jawa Tengah, Pemerintah Kabupaten Sragen telah menetapkan 7 klaster usaha, yaitu Klaster Sapi, Konveksi, Alat Rumah Tangga, Ikan, Meubel, Batik, dan Padi Organik. Pengembangan UKM melalui klaster tersebut diharapkan dapat meningkatkan konstribusi industri pengolahan terhadap PDRB Kabupaten Sragen, dari Industri pengolahan di Kabupaten Sragen yang potensial antara lain konveksi, mebel dan baik. Dari sumber PDRB kabupaten Sragen 2013 Pertumbuhan ekonomi pertumbuhan PDRB per kapita kabupaten Sragen mulai tahun 2009-2013 setiap tahunnya mengalami peningkatan dari tahun 2009 sebesar Rp 3.306,50, tahun 2010 sebesar 3.486, 64, tahun 2011 sebesar 3.692,52, tahun 2012 sebesar 3.917,84 dan ditahun 2013 sebesar 4.157, 28.

Dari gambaran potensi daerah Kabupaten Sragen peneliti ingin menganalisis daya saing potensi ekonomi klaster UMKM Klaster Batik, Koveksi Dan Mebel di Kabupaten 
Sragen, yaitu sebagai berikut 1) Untuk menguji perubahan struktur ekonomi dan menentukan potensi spesialisasi suatu daerah terhadap aktifitas ekonomi yang utama atau menentukan sektor basis yaitu sektor ekonomi yang dapat memenuhi kebutuhan daerah sendiri dan daerah sendiri di Kabupaten Sragen. 2) Untuk menentukan prioritas kebijakan pengembangan klaster UMKM Sragen yang terdiri dari klaster mebel, batik dan konveksi di Kabupaten Sragen. 3)Untuk menganalisis evaluasi kebijakan yang pernah dilakukan Pemerintah Kabupaten Sragen terhadap pengembangan UMKM klaster batik, konveksi dan mebel di Kabupaten Sragen.

\section{TINJAUAN PUSTAKA}

\section{Klaster UMKM}

Dalam bahasa sederhana klaster (cluster) berarti kelompok, namun tidak semua kelompok industri dapat disebut sebagai klaster. Definisi klaster secara sederhana adalah kumpulan perusahaan-perusahaan secara sektoral dan spasial yang didominasi oleh satu sektor. Definisi ini banyak digunakan oleh peneliti-peneliti klaster yang melakukan penelitian di negara berkembang (Schmitz dan Nadvi, 1999). Karakteristik kunci klaster atau industrial districts (Schmitz dan Musyck, 1993) sebagai berikut: (1) Didominasi oleh usaha kecil yang beraktivitas pada sektor yang sama (spesialisasi pada sektor) atau sektor yang berhubungan; (2) Kolaborasi antar usaha yang berdekatan dengan berbagi peralatan, informasi, tenaga kerja terampil, dan lain sebagainya; (3) Perusahaan-perusahaan tersebut saling bersaing dengan lebih berdasarkan pada kualitas produk daripada menurunkan ongkos produksi termasuk upah; (4) Pengusaha dan pekerja memiliki sejarah panjang pada lokasi tersebut. Hal ini memudahkan saling percaya dalam berhubungan baik antara usaha kecil, antara pekerja, dan tenaga kerja terampil; (5) Pengusaha diorganisir dengan baik dan berpartisipasi aktif dalam organisasi mandiri; (6) Ada pemerintahan lokal dan regional yang aktif mendukung pengembangan klaster industri lokal atau daerah.

Pembentukan klaster (clustering) juga didefinisikan sebagai proses dari unitunit usaha dan aktor-aktor terkait untuk membangun usahanya pada lokasi yang sama dalam area geografis tertentu, yang selanjutnya bekerja sama dalam lingkungan fungsional tertentu, dengan mewujudkan keterkaitan dan kerjasama yang erat untuk meningkatkan kemampuan kompetisi bersama (collective competitiveness) dalam suatu pertalian usaha. Dalam definisinya Porter (1990) juga lebih menekankan pada konsep pertalian usaha yang bernilai (value chain) dalam rangka menghasilkan suatu jenis produk. Kedekatan jarak antar kelompok usaha selanjutnya dapat diterjemahkan menjadi ukuran nilai tambah optimal karena adanya aglomerasi. Dampak kompetisi dalam klaster menyebabkan peningkatan produktivitas perusahaan melalui inovasi dan perluasan serta perkuatan perusahaan di dalam klaster itu sendiri (Porter, 1998). Berdasarkan data dari BPS. Industri dikelompokkan menjadi empat yaitu (a) industry hasil pertanian dan kehutanan, (b) aneka industri, (c) industri logam \& mesin, dan (d) industri kimia baik industry besar maupun kecil

\section{Strategi Pengembangan Ekonomi Kerakyatan \\ Strategi merupakan serangkaian} tindakan yang digunakan untuk merumuskan, mengimplementasikan, dan mengevaluasi keputusan manajerial dalam mencapai sasaran perusahaan (Hunger \& Wheelen, 2003; Hunger \& Wheelen, 2007). Strategi memiliki keterkaitan yang erat hubungannya dengan konsep perencanaan dan pengambilan keputusan, sehingga pada akhirnya strategi bekembang menjadi manajemen strategi. Proses manajemen strategi terdiri dari beberapa tahapan, diantaranya pengamatan lingkungan, perumusan strategi, implementasi strategi dan evaluasi strategi (David, 2004; Hunger \&Wheelen, 2007). Tahap pengamatan lingkungan dilakukan untuk mengidentifikasi 
berbagai peristiwa, perkembangan dan perubahan lingkungan yang mempengaruhi kondisi organisasi (Hunger \& Wheelen, 2003; Hunger \& Wheelen, 2007; Hill \& Jones,2009). Tahap perumusan strategi adalah tahap pemilihan keputusan dalam pemilihan alternative strategi yang akan digunakan oleh organisasi. Strategi yang dipilih merupakan hasil dari pengamatan terhadap lingkungan organisasi (Hunger\& Wheelen, 2007; Thompson, 2010). Tahap selanjutnya adalah tahap implementasi strategi, yaitu tahap pelaksanaan strategi yang telah dirumuskan atau direncanakan.

Implementasi strategi merupakan proses dimana manajemen mewujudkan strategi dan kebijakannya melalui pembangunan program, anggaran dan prosedur (David,2004; Harrison \& John, 2009). Tahap terakhir ialah evaluasi dan pengendalian yaitu melakukan perbandingan hasil yang diperoleh dengan hasil yang diinginkan untuk memberikan umpan balik yang diperlukan bagi pihak manajemen untuk mengevaluasi dan mengambil tindakan perbaikan bila diperlakukan (Hunger \&Wheelen, 2007; Hill \& Jones, 2009).

\section{Produk Unggulan}

Produk Unggulan Daerah yang selanjutnya disingkat PUD merupakan produk, baik berupa barang maupun jasa, yang dihasilkan oleh koperasi, usaha skala kecil dan menengah yang potensial untuk dikembangkan dengan memanfaatkan semua sumber daya yang dimiliki oleh daerah baik sumber daya alam, sumber daya manusia dan budaya lokal, serta mendatangkan pendapatan bagi masyarakat maupun pemerintah yang diharapkan menjadi kekuatan ekonomi bagi daerah dan masyarakat setempat sebagai produk yang potensial memiliki daya saing, daya jual, dan daya dorong menuju dan mampu memasuki pasar global.

Penetapan Produk Unggulan Daerah dapat memenuhi kriteria sebagai berikut: Penyerapan tenaga kerja; Sumbangan terhadap perekonomian; Sektor basis ekonomi daerah; Dapat diperbaharui; Sosial budaya; Ketersediaan pasar; Bahan baku; Modal; Sarana dan prasarana produksi; Teknologi; Manajemen usaha; Harga. Dengan pertimbangan kekhususan dan kewenangan yang dimiliki pemerintah provinsi dan kabupaten/kota dapat menggunakan sebagian besar kriteria yang digunakan untuk menentukan produk unggulan daerah kecuali kriteria huruf a sampai dengan huruf f bersifat mutlak harus terpenuhi. Kriteria PUD menurut Permendagri No . 9 tahun 2014 adalah:

1. Penyerapan tenaga kerja produk unggulan daerah diproduksi dengan memanfaatkan tenaga kerja terampil di daerah produksi sehingga memberi dampak pada penciptaan lapangan kerja dan pendapatan bagi masyarakat setempat.

2. Sumbangan terhadap perekonomian merupakan produk yang memiliki nilai ekonomis memberikan manfaat bagi konsumen, memiliki keterkaitan ke depan dan kebelakang, memberi efek berganda ekonomi dan sekaligus memberikan keuntungan ekonomi bagi seluruh pemangku kepentingan dan daerah yang memproduksi produk unggulan tersebut.

3. Sektor basis ekonomi daerah merupakan produk unggulan daerah yang masuk dalam kategori kelompok sektor basis dalam PDRB dan memberikan kontribusi terbesar dalam ekonomi daerah.

4. Dapat diperbaharui memberi makna bahwa produk unggulan daerah bukan barang tambang dan memanfaatkan bahan baku yang dapat diperbaharui dan ramah lingkungan. Barang tambang tidak dapat dimasukkan sebagai produk unggulan daerah meskipun saat itu memberi kontribusi ekonomi yang besar bagi daerah.

5. Unsur sosial budaya dalam menciptakan, memproduksi dan mengembangkan produk unggulan daerah adalah menggunakan talenta dan kelembagaan masyarakat yang dibangun dan dikembangkan atas dasar kearifan lokal 
yang bersumber pada ciri khas dan warisan budaya turun temurun serta kondisi sosial budaya setempat.

5. Ketersediaan pasar adalah kemampuan produk unggulan daerah untuk terserap pada pasar lokal, regional dan nasional serta berpotensi untuk memasuki pasar global.20 |

6. Bahan baku terjamin ketersediaannya dengan perolehan harga yang kompetitif, terjamin kesinambungannya serta ramah lingkungan.

7. Modal adalah ketersediaan dan kecukupan dana bagi kelancaran usaha untuk kebutuhan investasi dan modal kerja.

8. Sarana dan prasarana produksi adalah kemudahan bagi pengusaha PUD untuk memperoleh sarana dan prasarana produksi pada tingkat harga yang kompetitif dan mudah diperoleh.

9. Teknologi yang relevan, tepat guna dan terdapat unsur yang tidak mudah ditiru.

10. Manajemen usaha merupakan kemampuan mengelola usaha secara profesional dengan memanfaatkan talenta dan kelembagaan masyarakat.

11. Harga merupakan kemampuan memberi nilai tambah dan mendatangkan laba usaha.

\section{METODE PENELITIAN}

\section{Desain Penelitian}

Penelitian ini menggunakan pendekatan kuantitatif. Pendekatan kuantitatif yang digunakan dalam penelitian ini adalah dengan menggunakan metode survei. Dalam penelitian survei, informasi dikumpulkan dari responden dengan menggunakan kuesioner. Metode survei menurut Singarimbun (1989), adalah penelitian yang mengambil sampel dari satu populasi dan menggunakan kuesioner sebagai alat pengumpulan data yang pokok.

\section{Populasi dan Sampel}

Berdasarkan populasi yang ada, maka dipergunakan metode pengambilan sampel yaitu stratified sampling dan purposive sampling. Stratified Sampling adalah cara mengambil sample dengan memperhatikan strata (tingkatan) didalam populasi. Dalam stratified data sebelumnya dikelompokan kedalam tingkat-tingkatan tertentu (Pengusaha yang telah menguasai proses awal sampai dengan akhir maupun yang mempunyai jaringan pemasaran). Purposive sampling adalah metode pengambilan sampel dengan kriteria tertentu, kriteria adalah stakeholder yang merupakan pelaku industri di tiga klaster (UMKM) di Kabupaten Sragen.

\section{Metode Pengumpulan Data}

Metode pengumpulan data dalam kegiatan Survei dan Analisis Potensi Ekonomi Klaster Batik, Konveksi dan Mebel di Kabupaten Sragen ini adalah:

1. Survei. Metode ini dilakukan untuk mengumpulkan data melalui kuisioner yang terstuktur

2. Indeph Interview. Dilakukan untuk mempertajam hasil survei dengan melakukan wawancara kepada responden kunci

3. Studi Dokumen. Memperkuat hasil temuan survei yang di komparasikan dengan data yang sudah ada.

\section{Alat Analisis Data}

Analisis Data yang digunakan dalam kegiatan Survei dan Analisis Potensi Ekonomi Klaster Batik, Konveksi dan Mebel di Kabupaten Sragen ini adalah sebagai berikut.

1. Analisis LQ dan shift share untuk melihat perkembangan perekonomian secara umum maupun secara khusus untuk data sektor dan subsektor ekonomi, sehingga posisi perekonomian daerah dapat diketahui baik tingkat kemajuan, tingkat basis ekonomi, keunggulan maupun potensi ekonomi daerah.

2. Analisis AHP untuk menyusun strategi pengembangan UKM klaster batik, konveksi dan mebel di Kabupaten Sragen

3. Analisis Topsis untuk evaluasi kebijakan yang pernah dilakukan 
Pemerintah Kabupaten Sragen terhadap pengembangan UKM klaster batik, konveksi dan mebel

\section{ANALISIS DAN PEMBAHASAN}

\section{Pengembangan Klaster Batik, Mebel dan Konveksi}

Pembangunan ekonomi daerah Kabupaten Sragen yang berkesinambungan harus didasarkan pada perencanaan yang baik sesuai dengan potensi sumber daya daerah yang dimilikinya. Pembangunan ekonomi daerah salah satunya terkait dengan sektor unggulan daerah. Sektor unggulan di Kabupaten Sragen ini diperoleh melalui dua alat analisis, yaitu analisis shift share dan location quotient.

\section{Analisis Shift Share}

Tujuan analisis ini adalah untuk menentukan produktivitas kerja perekonomian Kabupaten Sragen terhadap perekonomian provinsi Jawa Tengah. Variabel yang biasa digunakan adalah PDRB Kabupaten Sragen tahun 2009-2013 dan PDRB Propinsi Jawa Tengah tahun 2009-2013. Analisis Shift Share adalah salah satu alat analisis yang digunakan untuk mengidentifikasi sumber pertumbuhan ekonomi, baik dari segi pendapatan maupun dari sisi tenaga kerja pada suatu wilayah tertentu (Harisman, 2007).

Berdasarkan dari hasil perhitungan shift share tahun 2009-2013 sebagaimana pada tabel di bawah, diketahui bahwa sektor usaha yang memiliki komponen + Proportional Share (positif) adalah delapan sektor, kecuali sektor pertanian. Hasil menunjukkan bahwa delapan sektor di Kabupaten Sragen memiliki pertumbuhannya relatif lebih tinggi dibandingkan dengan pertumbuhan sektor sejenis di Propinsi Jawa Tengah. Sedangkan sektor pertanian pertumbuhannya relatif lebih rendah dari pertumbuhan sektor sejenis di Propinsi Jawa Tengah. Hal ini dapat dilihat dari nilai Proportional Share yang negatif.

Tabel 1. Hasil Perhitungan Analisis Shift Share

\begin{tabular}{|c|c|c|c|c|}
\hline Sektor & $\begin{array}{l}\text { Provinsional } \\
\text { Share }\end{array}$ & $\begin{array}{l}\text { Proportional } \\
\text { Share }\end{array}$ & $\begin{array}{l}\text { Defferential } \\
\text { Share }\end{array}$ & Total Shif Share \\
\hline Pertanian & $256.737,12$ & $-158.960,38$ & $105.147,05$ & 202.924 \\
\hline Pertambangan dan Penggalian & $2.236,70$ & 195,45 & $-277,13$ & 2.155 \\
\hline Industri Pengolahan & $166.045,64$ & $7.923,05$ & $19.855,14$ & 193.824 \\
\hline Listrik, Gas dan Air Bersih & $9.120,29$ & $2.269,20$ & $-405,25$ & 10.984 \\
\hline Bangunan & $33.664,68$ & $5.918,17$ & $-1.441,85$ & 38.141 \\
\hline Perdagangan, Hotel dan Restoran & $138.933,39$ & $37.126,26$ & $20.950,88$ & 197.011 \\
\hline Pengangkutan dan komunikasi & $24.696,23$ & $6.775,45$ & $2.569,38$ & 34.041 \\
\hline $\begin{array}{l}\text { Keuangan, Sewa dan Jasa } \\
\text { Perusahaan }\end{array}$ & $30.483,46$ & $11.009,56$ & $-3.115,97$ & 38.377 \\
\hline Jasa- Jasa & $93.091,88$ & $14.380,91$ & $-868,35$ & 106.604 \\
\hline Jumlah & $752.291,07$ & $8.050,47$ & $63.719,42$ & 824.061 \\
\hline
\end{tabular}

Sektor ekonomi di Kabupaten Sragen yang mempunyai nilai komponen Defferential Share positif adalah sektor pertanian, sektor industri pengolahan, sektor perdagangan, hoter dan restoran, sektor angkutan dan komunikasi. Keempat sektor ini mempunyai daya saing yang lebih tinggi dibandingkan dengan daya saing Provinsi Jawa Tengah.

Berdasarkan analisis Total Shift Share sebagaimana di atas, dapat ditarik kesimpulan bahwa produktivitas semua sektor ekonomi di Kabupaten Sragen adalah sejalan dengan 
produktivitas sektor ekonomi di Propinsi Jawa Tengah. Simpulan ini dapat dilihat dari nilai Total Shif Share yang positif.

\section{Analisis Location Quotient (LQ)}

Salah satu cara dalam menentukan suatu sektor sebagai sektor basis atau non-basis adalah analisis Location Quotient (LQ). Arsyad (1999) menjelaskan bahwa teknik Location Quotient dapat membagi kegiatan ekonomi suatu daerah menjadi dua golongan yaitu:

1. Kegiatan sektor ekonomi yang melayani pasar di daerah itu sendiri maupun di luar daerah yang bersangkutan. Sektor ekonomi seperti ini dinamakan sektor ekonomi potensial (basis).
2. Kegiatan sektor ekonomi yang melayani pasar di daerah tersebut dinamakan sektor tidak potensial (non basis).

Dari data yang digunakan dalam analisis ini adalah PDRB Kabupaten Sragen tahun 2009-2013 dan Provinsi Jawa Tengah tahun 2009-2013. Dalam hal ini perkembangan LQ bisa dilihat untuk suatu komoditi tertentu dalam kurun waktu yang berbeda, apakah terjadi kenaikan atau penurunan (Tarigan, 2005). Berdasarkan perhitungan LQ tahun 2009-2013 diketahui bahwa lapangan usaha di Kabupaten Sragen secara umum relatif stabil.

Tabel 2. Hasil Perhitungan Location quotient (LQ) Kabupaten Sragen

\begin{tabular}{lcccccc}
\hline \multicolumn{1}{c}{ Lapangan usaha } & $\mathbf{2 0 0 9}$ & $\mathbf{2 0 1 0}$ & $\mathbf{2 0 1 1}$ & $\mathbf{2 0 1 2}$ & $\mathbf{2 0 1 3}$ & Rata2 \\
\hline Pertanian & 1,063 & 1,127 & 1,204 & 1,225 & 1,273 & 1,178 \\
Pertambangan dan Penggalian & 0,163 & 0,164 & 0,171 & 0,172 & 0,174 & 0,169 \\
Industri Pengolahan & 0,413 & 0,430 & 0,453 & 0,463 & 0,461 & 0,444 \\
Listrik, Gas dan Air Bersih & 0,874 & 0,885 & 0,930 & 0,933 & 0,945 & 0,913 \\
Bangunan & 0,466 & 0,477 & 0,494 & 0,496 & 0,504 & 0,488 \\
Perdagangan, Hotel dan Restoran & 0,525 & 0,556 & 0,581 & 0,586 & 0,589 & 0,567 \\
Pengangkutan dan komunikasi & 0,383 & 0,403 & 0,415 & 0,419 & 0,427 & 0,409 \\
Keuangan, Sewa dan Jasa Perusahaan & 0,649 & 0,689 & 0,719 & 0,713 & 0,694 & 0,693 \\
Jasa- Jasa & 0,750 & 0,770 & 0,800 & 0,806 & 0,816 & 0,788 \\
\hline
\end{tabular}

Sumber: Hasil Perhitungan $L Q(2017)$

Dari perhitungan LQ untuk 5 (lima) tahun terakhir, sektor ekonomi yang memiliki nilai LQ $>1$ adalah sektor pertanian. Dengan demikian, sektor-sektor tersebut merupakan sektor basis (B) atau sektor unggulan dalam pembangunan ekonomi di Kabupaten Sragen pada tahun 2009-2013. Sektor yang memiliki nilai $\mathrm{LQ}<1$ (sektor non basis) yaitu seluruh sektor selain pertanian. 


\section{Analisis Sektor Unggulan berdasarkan Nilai PDRB, analisis shift share dan analisis $L Q$}

Tabel. 3. Hasil Analisis Shift share dan LQ Menurut Lapangan Usaha

\begin{tabular}{lcccc}
\hline \multicolumn{1}{c}{ Lapangan Usaha } & Nilai PDRB (jutaan) & $\begin{array}{c}\text { Shift } \\
\text { Share }\end{array}$ & LQ & Prioritas \\
\hline Pertanian & $1.179 .919,15$ & + & $\mathrm{B}$ & 1 \\
Pertambangan, dan penggalian & $10.757,73$ & + & $\mathrm{NB}$ & 3 \\
Industri Pengolahan & $832.460,93$ & + & $\mathrm{NB}$ & 2 \\
Listrik, gas dan air bersih & $46.062,26$ & + & $\mathrm{NB}$ & 3 \\
Bangunan & $167.620,54$ & + & $\mathrm{NB}$ & 3 \\
Perdagangan, Hotel dan Restoran & $731.369,72$ & + & $\mathrm{NB}$ & 2 \\
Pengangkutan dan komunikasi & $129.026,57$ & + & $\mathrm{NB}$ & 3 \\
Keuangan, Sewa dan Jasa Perusahaan & $155.621,11$ & + & $\mathrm{NB}$ & 3 \\
Jasa- Jasa & $464.650,14$ & + & $\mathrm{NB}$ & 3 \\
\hline
\end{tabular}

Sumber: Hasil Perhitungan Shift Share dan $L Q$, terlampir

Sektor ungulan prioritas pertama di Kabupaten Sragen adalah pertanian. Sektor ini memiliki sumbangan nilai PDRB yang paling besar dibanding 8 sektor lain. Sektor ini juga memiliki daya saing yang bagus di provinsi Jawa Tengah serta merupakan sektor basis, meskipun pertumbuhan dalam 5 tahun terkhir lebih rendah jika dibandingkan dengan rata rata pertumbuhan kabupaten/kota di Jawa Tengah.

Sektor industri pengolahan berada pada prioritas kedua, sama dengan sektor perdagangan, hotel dan restoran. Sektor industri pengolahan yang didalamya ada klaster batik, mebel dan konveksi memiliki sumbangan nilai PDRB yang besar, dan menempati peringkat kedua. Sektor ini juga memiliki daya saing dan pertumbuhan yang bagus di Provinsi Jawa Tengah, akan tetapi sektor ini bukan merupakan sektor basis di Kabupaten Sragen.

\section{Prioritas Kebijakan Pengembangan Klaster}

Menurut Saaty (1993) jumlah elemen dalam suatu model hirarki hendaknya berjumlah 5 sampai 9, agar dapat dibandingkan secara bermakna terhadap elemen yang berada setingkat diatasnya. Untuk itu peneliti melakukan pengelompokan kriteria-kriteria tersebut ke dalam tiga kelompok faktor yang sesuai dengan tujuan pengembangan produk unggulan menurut Depperin (2009), yaitu peningkatan daya saing, peningkatan perekonomian daerah serta pembangunan yang berwawasan lingkungan. Faktor daya saing dikelompokkan menurut teori daya saing klaster industri menurut model Diamond Porter (1990,1998), variabel yang merupakan indikator ekonomi dikelompokkan kedalam kriteria sumbangan terhadap perekonomian daerah.

Berdasarkan analisa dan pengelompokan di atas, maka ditetapkan kriteria penentuan produk

unggulan Kota Malang berbasis klaster sebagaimana berikut:

$\mathrm{K} 1=$ Produk unik/khas/trade mark daerah

$\mathrm{K} 2=$ Sumbangan terhadap perekonomian daerah

$\mathrm{K} 3=$ Pasar

$\mathrm{K} 4=$ Kondisi input (ketersediaan infrastruktur, SDM, teknologi, modal)

$\mathrm{K} 5=$ Kemitraan

K6 = Dukungan kebijakan dan kelembagaan

$\mathrm{K} 7=$ Dampak terhadap lingkungan

$\mathrm{K} 8=$ Tingkat daya saing

Berdasarkan analisis AHP prioritas kebijakan pengembangan klaster UMKM di 
Sragen meliputi 9 kebijakan sesuai dengan prioritas kepentingannya. Penentuan prioritas kebijakan pengembangan klaster UMKM Sragen yang terdiri dari klaster mebel, batik dan konveksi dilakukan dengan kombinasi antara pengamatan terhadap data deskriptif dan hasil wawancara dengan beberapa pelaku ekonomi klaster UMKM dan pengambil kebijakan di level SKPD Kabupaten Sragen. Verifikasi terhadap kriteria yang telah diidentifikasi diperlukan agar memperoleh kriteria yang operasional, spesifik, efisien dan efektif. Setelah diverifikasi, ditetapkan kriteria penentu prioritas strategi pemasaran (Wulandari, 2009).

Model AHP dari kajian ini dikembangkan berdasarkan konsep Value Chain atau Rantai Nilai dari proses bisnis dalam sebuah industry. Ada 9 faktor yang dinilai dari model prioritas kebijakan dalam model AHP kajian ini, yaitu bahan baku, tenaga kerja, harga produk, pasar, teknologi, modal, manajemen, basis perekonomian dan sosial budaya. Faktor-faktor ini kemudian dijadikan bahan wawancara dan kuesioner dengan para pelaku dan pengambil kebijakan. Tabel 4.6. menunjukkan hasil analisis AHP dari faktor-faktor rantai nilai klaster UMKM.

Tabel 4. Pembobotan Faktor Prioritas

\begin{tabular}{clc}
\hline No & \multicolumn{1}{c}{ Faktor Prioritas } & Bobot \\
\hline $\mathbf{1}$ & Pasar & 0.224 \\
$\mathbf{2}$ & Harga & 0.179 \\
$\mathbf{3}$ & Manajemen & 0.142 \\
$\mathbf{4}$ & Basis & 0.115 \\
$\mathbf{5}$ & Tenaga Kerja & 0.91 \\
$\mathbf{6}$ & Modal & 0.78 \\
$\mathbf{7}$ & Bahan Baku & 0.68 \\
$\mathbf{8}$ & Teknologi & 0.62 \\
$\mathbf{9}$ & Sosial Budaya & 0.41 \\
\hline \multicolumn{2}{c}{ Sumber : Hasil Olahan Data (2017) }
\end{tabular}

Verifikasi terhadap kriteria yang telah diidentifikasi diperlukan agar memperoleh kriteria yang operasional, spesifik, efisien dan efektif. Setelah diverifikasi, ditetapkan kriteria penentu prioritas strategi pemasaran (Wulandari, 2009). Hasil analisis AHP dari Tabel menunjukkan bobot masingmasing faktor yang menjadi panduan dalam menentukan prioritas kebijakan pengembangan klaster mebel, batik dan konveksi di kabupaten Sragen. Hasil analisis AHP terlihat faktor tersebut mempunyai tingkat inkonsistensi sebesar 0.09. Penjelasan tentang prioritas kebijakan UMKM tersebut adalah:

1. Pasar.

Pengertian pasar secara lengkap adalah semua pelanggan mempunyai kebutuhan dan keinginan tertentu, bersedia dan mampu melibatkan diri dalam suatu kondisi (Kotler dan Keller, 2009;6). Klaster mebel dan batik mempunyai peluang untuk mengembangkan pasar ekspor karena kandungan bahan baku dari dua produk klaster ini lebih dari 50 persen. Nilai Rupiah terhadap Dollar AS yang mengalami pelemahan berpeluang meningkatkan daya saing harga produk ini. Klaster konveksi mempunyai kondisi berbeda. Produk konveksi mempunyai bahan baku impor diatas $70 \%$ yang terdiri dari benang dan bahan pewarna. Komponen biaya yang mengalami peningkatan menyebabkan produk konveksi perlu membenahi komponen produk dengan terobosan terkait dengan mencari bahan baku dan pewarna substitusi.

2. Harga.

Prioritas kebijakan harga perlu dilakukan SKPD yang terkait dengan pengembangan UMKM dengan memberikan pelatihan tentang penentuan harga pokok penjualan kepada UMKM mebel dan konveksi. Pemberian insentif kepada UMKM terkait dengan komponen harga yang membebani produksi juga perlu dilakukan. Sebagai contoh, pemberian insentif untuk pembelian bahan baku dan sertifikasi kayu bagi klaster UMKM mebel bisa menjadi salah satu kebijakan pengembangan klaster UMKM. Pelatihan tentang penggunaan pewarna kain alami dan ramah lingkungan dengan bahan dari 
alam sekitar juga bisa menjadi pilihan bagi SKPD pembina klaster UMKM batik untuk membantu mereka mendapatkan biaya yang lebih rendah terkait dengan penggunaan bahan pewarna untuk kain batik.

\section{Manajemen}

Perusahaan konveksi mempunyai ukuran perusahaan yang lebih besar dibandingkan dengan klaster mebel dan batik dengan jumlah karyawan rata-rata diatas 20 orang. Hal ini menunjukkan ukuran perusahaan masuk kategori kecil dan menengah sehingga penerapan manajemen moderen diperlukan bagi pengembangan klaster UMKM. Klaster mebel dan batik memerlukan stimulus penerapan manajemen moderen dari sisi pemasaran. Kebijakan ini termasuk desain produk yang bagus, analisis dan segmentasi pasar serta komunikasi pemasaran.

4. Basis Ekonomi.

Regulasi atau perda dengan tujuan yang spesifik ini misalnya kemudahan investasi, regulasi tentang akses permodalan serta insentif bagi klaster UMKM yang mampu menyerap banyak tenaga kerja. Penyusunan regulasi yang berupa perda atau perbup ini tetap harus mengacu pada undang-undang di atasnya, sehingga tidak bertabrakan dengan aturan yang lebih tinggi.

5. Tenaga Kerja

Pelatihan bagi individu yang berkaitan dengan teknologi berpengaruh terhadap efektivitas transfer teknologi. Pelatihan berpengaruh terhadap kemampuan absorpsi dan aplikasi teknologi baru (Samli, 1985; Mahboudi dan Ananthan, 2010). Pelatihan dapat didefinisikan sebagairangkaian kegiatan yang terencana yang bertujuan untuk mendapatkan pengalaman belajar yang akan dapat memberikan sumbangan oleh karyawan dalam mencapai tujuan perusahaan, sehingga pelatihan ikut mempengaruhi transfer teknologi (Sutaryo, 2003).
Pendapatn diatas sependapat dengan temuan yang ada di kluster UMKM Kab. Sragen, Sudah saatnya klaster UMKM Sragen mendapatkan pasokan tenaga kerja terampil yang berasal dari lembaga pendidikan formal bersertifikasi atau berijazah. Kerjasama dengan perguruan tinggi dan politeknik ataupun SMK di wilayah Solo Raya diperlukan untuk mendapatkan pasokan tenaga kerja terampil ini.

6. Modal

Pemahaman yang belum lengkap tentang modal menyebabkan perbankan raguragu untuk memberikan kredit investasi. Beberapa perbankan sebenarnya menawarkan kredit mikro dengan agunan ringan, namun mereka mensyaratkan penyusunan laporan keuangan dan prospektus bisnis yang lengkap. Dokumen ini menuntut perlunya pemahaman komprehensif tentang manajemen keuangan perusahaan.

7. Bahan baku

Apabila bahan baku berkualitas buruk maka hal ini akan berpengaruh terhadap kualitas produk yang dihasilkan dan otomatis berdampak pada berhasil atau tidaknya suatu perusahaan dalam menciptakan hasil usahanya (Taufik et al., 2014). Hal ini disebabkan karena pembelian bahan baku sangat mempengaruhi bentuk atau komposisi produk jadi baik secara kuantitas maupun kualitas serta harga jual produk. Dari hasil penelitian ini bahan baku impor dengan harga yang tidak stabil memerlukan terobosan dari pelaku usaha dan pemerintah untuk mencari bahan substitusi. Menstimulus pelaku usaha klaster UMKM batik dan konveksi untuk mencari bahan pewarna organik dengan bahan baku lokal layak untuk dilakukan.

\section{Teknologi}

Faktor lingkungan memiliki dampak yang signifikan terhadap kinerja transfer teknologiStrategi transfer teknologi akan lebih efektif jika semua pihak menyadari 
pentingnya lingkungan transfer teknologi (Mohamed et al., 2009). Sedangkan untuk penelitian ini bantuan teknologi dengan memanfaatkan Sragen Techno Park dengan penguatan mesin-mesin produksi yang dipergunakan bersama oleh unit usaha yang ada dalam klaster UMKM bisa menjadi sebuah pilihan kebijakan yang layak dipertimbangkan. Penggunaan teknologi tidak terbatas pada mesin dan alat produksi, namun juga dengan menggunakan teknologi untuk aktivitas pemasaran, baik dalam proses transaksi, komunikasi pemasaran maupun membangun jaringan pemasaran.

9. Sosial Budaya

Kepercayaan dan nilai budaya pada kelompok pekerja yang berbeda memiliki dampak yang nyata terhadap bagaimana mereka membangun arti dari teknologi yang mereka gunakan ketika bekerja maupun untuk keperluan pribadi.Ciriciri budaya dari dua belah pihak dapat memiliki dampak yang signifikan pada efektivitas dan karenanya mempengaruhi keberhasilan proses transfer teknologi (Mohamed dkk, 2010). Untuk itu Kekuatan utama kebijakan yang terkait dalam penguatan klaster UMKM dalam penelitian ini dengan aspek sosial budaya adalah membangun brand bagi produk klaster UMKM. Membangun brand dengan ciri khas Sragen. Kekhasan ini bisa dalam bentuk desain produk, warna dan pola maupun nama produk yang dihasilkan. Selanjutnya konsep brand tersebut dikomunikasikan dengan dengan jalur komunikasi pemasaran yang terintegrasi.

Tabel 5. Faktor Prioritas Masing-Masing Klaster UMKM

\begin{tabular}{llcccccccccc}
\hline \multirow{2}{*}{ No } & $\begin{array}{c}\text { Faktor } \\
\text { Prioritas }\end{array}$ & $\begin{array}{c}\text { Tenaga } \\
\text { Kerja }\end{array}$ & $\begin{array}{c}\text { Bahan } \\
\text { Baku }\end{array}$ & Teknologi & Manajemen & Harga & Pasar & Modal & $\begin{array}{c}\text { Sosial } \\
\text { Budaya }\end{array}$ & Basis \\
\hline 1 & Mebel & 0.634 & 0.413 & 0.200 & 0.491 & 0.493 & 0.169 & 0.297 & 0.263 & 0.157 \\
2 & Konveksi & 0.174 & 0.260 & 0.400 & 0.311 & 0.196 & 0.443 & 0.540 & 0.190 & 0.594 \\
3 & Batik & 0.192 & 0.327 & 0.400 & 0.196 & 0.311 & 0.387 & 0.163 & 0.547 & 0.249 \\
\hline
\end{tabular}

Sumber : Hasil Olahan Data (2017)

Prioritas Kebijakan Untuk Masing-masing Klaster UMKM

\section{Klaster Mebel.}

Berdasarkan hasil analisis AHP klaster mebel Sragen mempunyai keunggulan dari sisi tenaga kerja, bahan baku, manajemen dan harga (tabel 4.16). Jumlah tenaga kerja klaster mebel Kabupaten Sragen sebagian besar 1 sd 5 orang atau $72 \%$ dari seluruh pelaku usaha di klaster mebel. Jumlah tenaga kerja relatif sedikit, namun masing-masing tenaga kerja memiliki keterampilan dan keahlian khusus berdasarkan tacit knowledge (pengalaman kerja dan bisnis). Hal ini merupakan sebuah keunggulan, hanya saja tanpa adanya pendidikan dan pelatihan tenaga kerja tersertifikasi sulit untuk membangun standar kualitas produk mebel di klaster ini.

Tabel 6. Prioritas Kebijakan Klaster Mebel Kabupaten Sragen

\begin{tabular}{clc}
\hline No. & \multicolumn{1}{c}{ Faktor Prioritas } & Bobot \\
\hline 1. & Tenaga Kerja & 0,634 \\
2. & Bahan Baku & 0,413 \\
3. & Manajemen & 0,493 \\
4. & Harga & 0,493 \\
\hline \multicolumn{2}{c}{ Sumber : Hasil Olahan Data (2017) }
\end{tabular}

Pola pengelolaan usaha dengan sudah dilakukan pada level moderat karena manajemen moderen pada pelaku usaha mebel mereka banyak berinteraksi dengan eksportir 
yang mempunyai tuntutan standardisasi kualitas tertentu yang harus dipenuhi. Pelaku usaha di klaster mebel sudah dapat mengakses pendanaan dari bank, karena klaster mebel telah memiliki manajemen keuangan yang baik. Kabupaten Sragen juga telah memiliki paguyuban atau asosiasi untuk para pelaku usaha mebel di Kabupaten Sragen.

Pembentukan harga produk mebel dipengaruhi oleh harga bahan baku. Bahan baku mebel banyak diperoleh dari pasar lokal yaitu Wonogiri, Karanganyar, Pacitan, Jogja dan Jepara. Pada penentuan bahan baku masih perlu pemahaman tentang sertifikasi bahan baku dan prosedurnya. Harga produk mebel bagi klaster UMKM mebel yang menjadi pemasok bagi eksportir bisa bersaing karena pelemahan nilai Rupiah terhadap Dollar AS, namun kondisi ini bersifat temporer sehingga perlu membangun daya saing harga berdasarkan efisiensi biaya produksi.

\section{Klaster Konveksi}

Berdasarkan analisis AHP dengan penurunan sub model rantai nilai klaster konveksi, maka ditemukan prioritas kebijakan yang merupakan keunggulan klaster konveksi terdiri dari teknologi, pasar, modal dan basis ekonomi. Teknologi pada klaster konveksi merupakan sisi unggul klaster ini karena mereka sudah menggunakan mesin moderen dan desain produk yang terus menerus mengalami perkembangan sesuai tuntutan pasar.

Pasar klaster konveksi adalah perusahaan konveksi besar yang memberikan pekerjaan sub kontrak dan juga beberapa peritel. Untuk pemasaran lokal meliputi wilayah Sragen sendiri, Solo, dan Karanganyar. Sedangkan untuk regional seperti Yogyakarta, Semarang Magelang, Magetan, Madiun dan beberapa dipasarkan di Blora dan Ngawi. Kemudian untuk yang nasional meliputi Jawa Timur, Jakarta, Kota - kota di Kalimantan, Sulawesi dan Sumatra. Industri Batik telah mempunyai tujuan ekspor yaitu Malaysia dan Singapura. Pasar yang sudah terbentuk ini menjamin stabilitas permintaan dari produk konveksi.
Modal bukan merupakan masalah karena skala industri pada klaster ini besar sehingga akses mereka terhadap lembaga keuangan lebih baik. Klaster konveksi sudah dapat memenuhi persyaratan pengajuan dana pada pihak perbankan. Terdapat $31 \%$ pelaku usaha konveksi memiliki modal kerja lebih dari 20 juta rupiah. Selain itu, peran perusahaan mitra yang memberikan pinjaman bahan baku menjadi solusi permodalan bagi klaster ini.

Dampak ekonomi dari klaster konveksi adalah besarnya daya serap tenaga kerja. Jumlah tenaga kerja klaster konveksi sebagian besar sebanyak $1<5$ orang yaitu 32\%. 29\% pelaku usaha konveksi memiliki $10<20$ orang tenaga kerja. Pelaku usaha konveksi yang memiliki tenaga kerja sebanyak $5<10$ orang mencapai $20 \%$ dan $19 \%$ memiliki $>20$ orang tenaga kerja.

Tabel 7. Prioritas Kebijakan Klaster Konveksi Kabupaten Sragen

\begin{tabular}{clc}
\hline No. & \multicolumn{1}{c}{ Faktor Prioritas } & Bobot \\
\hline 1. & Teknologi & 0,443 \\
2. & Pasar & 0,443 \\
3. & Modal & 0,540 \\
4. & Basis Ekonomi & 0,594 \\
\hline & Sumber : Hasil Olahan Data (2017)
\end{tabular}

\section{Klaster Batik}

Keunggulan utama klaster batik adalah dari sisi sosial budaya yang bisa menjadi sumber komunikasi pemasaran. Branding yang tepat dengan menggunakan pendekatan sosial budaya bisa menjadi nilai tambah ekonomi yang besar bagi perkembangan klaster ini.

Tabel. 8 Prioritas Kebijakan Klaster Batik

\begin{tabular}{ccc}
\hline No. & Faktor Prioritas & Bobot \\
\hline 1. & Sosial Budaya & 0,547 \\
\hline & Sumber $:$ Hasil Olahan
\end{tabular}

Sumber : Hasil Olahan Data (2017)

\section{Klaster Prioritas dalam Pengembangan Ekonomi Derah}

Berdasarkan Tabel diuraikan beberapa kombinasi antara 9 kreteria dan 3 alternatif prioritas pengembangan klaster UMKM di 
Kabupaten Sragen. Pertama, nilai kreteria untuk pengembangan klaster mebel, yaitu tenaga kerja trampil $(0,634)$, ketersediaan dan kondisi penggunaan bahan baku $(0,413)$, penggunaan teknologi $(0,200)$, penerapan manajemen $(0,491)$, harga $(4,493)$, aspek pasar $(0,169)$, ketersediaan modal $(0,297)$, aspek sosbud atao ciri khas $(0,263)$ dan sektor basis atau sumbangan ekonomi $(0,157)$.

Kedua, nilai kreteria untuk pengembangan klaster konveksi, yaitu tenaga kerja trampil $(0,174)$, ketersediaan dan kondisi penggunaan bahan baku $(0,260)$, penggunaan teknologi
$(0,400)$, penerapan manajemen $(0,311)$, harga $(0,196)$, aspek pasar $(0,443)$, ketersediaan modal $(0,540)$, aspek sosbud atao ciri khas $(0,190)$ dan sektor basis atau sumbangan ekonomi $(0,594)$. Ketiga, nilai kreteria untuk pengembangan klaster batik, yaitu tenaga kerja trampil $(0,192)$, ketersediaan dan kondisi penggunaan bahan baku $(0,327)$, penggunaan teknologi $(0,400)$, penerapan manajemen $(0,196)$, harga $(0,387)$, aspek pasar $(0,387)$, ketersediaan modal $(0,163)$, aspek sosbud atao ciri khas $(0,547)$ dan sektor basis atau sumbangan ekonomi $(0,249)$.

Tabel. 9 Kreteria Dan Alternatif Pengembangan UMKM Kabupaten Sragen

\begin{tabular}{lccccccccc}
\hline & MAX & MAX & MAX & MAX & MAX & MAX & MAX & MAX & MAX \\
\hline & $\begin{array}{c}\text { 1. } \\
\text { Tenaga } \\
\text { Kerja }\end{array}$ & $\begin{array}{c}\mathbf{2 .} \\
\text { bahan } \\
\text { Baku }\end{array}$ & $\begin{array}{c}\text { 3. } \\
\text { Teknologi }\end{array}$ & $\begin{array}{c}\text { M. } \\
\text { Mana- } \\
\text { jemen }\end{array}$ & $\begin{array}{c}\mathbf{5 .} \\
\text { harga }\end{array}$ & $\begin{array}{c}\mathbf{6 .} \\
\text { Pasar }\end{array}$ & $\begin{array}{c}\text { 7. } \\
\text { Modal }\end{array}$ & $\begin{array}{c}\text { 8. } \\
\text { Sos- } \\
\text { bud }\end{array}$ & $\begin{array}{c}\text { Sektor } \\
\text { basis }\end{array}$ \\
\hline 1.Mebel & 0,634 & 0,413 & 0,200 & 0,491 & 0,493 & 0,169 & 0,297 & 0,263 & 0,157 \\
2.Konveksi & 0,174 & 0,260 & 0,400 & 0,311 & 0,196 & 0,443 & 0,540 & 0,190 & 0,594 \\
3.Batik & 0,192 & 0,327 & 0,400 & 0,196 & 0,387 & 0,387 & 0,163 & 0,547 & 0,249 \\
\hline
\end{tabular}

Berdasarkan hasil analisis Topsis menggunakan sofware Sanna7 terhadap 9 (sembilan) kreteria pengembangan UMKM dan 3 alternatif klaster (mebel, konveksi dan batik) dapat dijelaskan bahwa konveksi merupakan klaster yang memiliki nilai paling tinggi atau berada pada urutan paling atas. Artinya usaha berkonveksi di Kabupaten Sragen menempati rangking paling baik berdasarkan 9 kreteria yaitu bahan baku, tenaga kerja, harga produk, pasar, teknologi, modal, manajemen, basis perekonomian dan sosial budaya. Peringkat dua untuk kondisi klaster yang baik adalah mebel dan ketiga adalah batik.

Tabel. 10 Ranking kondisi klaster UMKM di Kabupaten Sragen

\begin{tabular}{clc}
\hline Ranking & \multicolumn{1}{c}{ Alternative } & R.U.V \\
\hline $\mathbf{1}$ & Konveksi & 0,50070 \\
$\mathbf{2}$ & Mebel & 0,49065 \\
$\mathbf{3}$ & Batik & 0,41577 \\
\hline \multicolumn{3}{c}{ Sumber: Hasil analisis (2017) }
\end{tabular}

Klaster konveksi di Kabupaten Sragen saat ini menempati urutan paling baik dari
3 klaster yang dianalisis, diikuti mebel dan batik. Dengan ini pengembangan klaster dapat dimulai dari klaster yang kondisinya paling rendah menuju ke klaster yang baik, yaitu klaster batik harus mendapat prioritas untuk dikembangkan, dikuti mebel dan konveksi.

Saat ini keunggulan klaster batik hanya dari faktor sosial budaya dari 8 lainnya, yaitu bahan baku, tenaga kerja, harga produk, pasar, teknologi, modal, manajemen, basis perekonomian. Satu keunggula klaster batik ini, yaitu batik merupakan ciri khas daerah Kabupaten Sragen, maka aspek ini dapat dijadikan sumber komunikasi pemasaran yang baik untuk pengembangan klaster ini. 


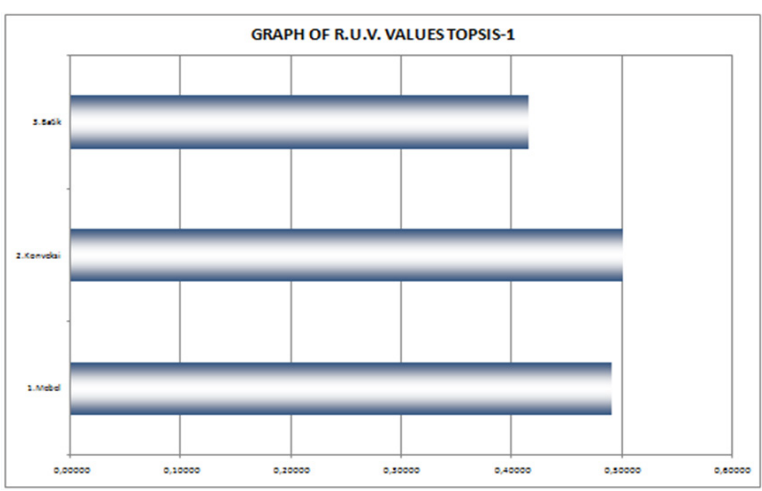

Gambar 1. Ranking Kondisi Klaster UMKM di Kabupaten Sragen

Sumber: Hasil analisis (2017)

\section{Simpulan}

\section{PENUTUP}

1. Sektor industri pengolahan Kabupaten Sragen, didalamya klaster batik, mebel dan konveksi memiliki sumbangan nilai PDRB yang besar, serta daya saing usaha dan pertumbuhan yang bagus dibandingkan dengan kabupaten/kota di Provinsi Jawa Tengah. Pembangunan sektor ini dapat meningkatkan laju pertumbuhan ekonomi daerah, penyediaan lapangan kerja, mengurangi jumlah kemiskinan, dan mengurangi pengangguran.

2. Evaluasi kebijakan pengembangan klaster batik, klaster konveksi dan klaster mebel di Kabupaten Sragen adalah Kebijakan dalam pengembangan pasar, kebijakan harga, penerapan manajemen, penguatan dampak ekonomi, penguatan tenaga kerja terampil, akses permodalan, ketersediaan dan stabilitas harga bahan baku, penguatan teknologi produksi dan branding produk dengan aspek sosial budaya.

3. Prioritas kebijakan pengembangan klaster Batik, Mebel dan Konveksi di Kabupaten Sragen adalah sebagai berikut:

a. Klaster mebel mempunyai beberapa prioritas kebijakan yang harus dikembangkan yaitu tenaga kerja, bahan baku, manajemen dan harga. b. Klaster konveksi mempunyai beberapa prioritas kebijakan yang harus dikembangkan yaitu teknologi, pasar, modal dan basis ekonomi.

c. Klaster batik mempunyai prioritas kebijakan yang harus dikembangkan yaitu aspek sosial budaya.

\section{Rekomendasi}

Para pengambil kebijakan di Sragen perlu melaksanakan kebijakan berikut ini untuk mengembangkan klaster UMKM di Sragen:

1. Pengembangan pasar dengan membangun jaringan pemasaran, melalui fasilitasi pameran, memanfaatkan dan membangun outlet bagi produk klaster UMKM. Kerjasama dengan pemprov maupun pemerintah pusat untuk memfasilitasi pameran dan membuka peluang ekspor.

2. Memberikanpelatihantentangmanajemen keuangan bagi pengusaha klaster UMKM terkait dengan meningkatkan pemahaman mereka tentang struktur biaya produksi, modal dan penyusunan harga pokok penjualan.

3. Memberikan pelatihan perencanaan bisnis, penyusunan standar kualitas, analisis pasar dan analisis persaingan bagi pengusaha klaster UMKM.

4. Menyusun regulasi kemudahan investasi dan memberikan stimulus bagi klaster UMKM yang mempunyai kemampuan untuk menyerap banyak tenaga kerja dan melakukan ekspor.

5. Bekerjasama dengan lembaga keuangan untuk melakukan pendampingan penyusunan laporan keuangan, analisis resiko dan prospektus bisnis sebagai syarat kredit UMKM tanpa agunan.

6. Melakukan pelatihan dan pendampingan sertifikasi bahan baku dan standardisasi kualitas bagi klaster UMKM.

7. Melaksanakan secara periodik acaraacara budaya yang dikaitkan dengan branding produk klaster UMKM. 


\section{DAFTAR PUSTAKA}

Arsyad, Lincolin, 1999, Pengantar Perencanaan dan Pembangunan Ekonomi Daerah. BPFE, Yogyakarta.

Harisman, Beni. 2007. Analisis Struktur Ekonomi dan Identifikasi Sektor sektor Unggula di Provinsi Lampung (periode 1993-2003)

Farrel, mark. 2000. Developing A Market Oriented learning Organization. Australian Journal of Management. Vol. 25 , pp. 201-217

Korpela, Jukka, Antti Lehmusvaara, Kalevi Kyläheiko dan Markku Tuominen (2003), Adjusting Safety Stock Requirements with an AHP-based Risk Analysis, Proceedings of the 36th Hawaii International Conference on System Sciences (HICSS'03).

Masri Singarimbun \& Sofian Effendi. 1989. Metode Penelitian Survei, Jakarta: LP3ES

Michael E. Porter (1990): "Competitive Strategy"., Techniques for Analysing Industries and Competitors., New York: The Free Press.

Moitra, Soumyo D (2006), Assessing The Value and Survivability of Network Information Systems, Working Paper Indian Institute of Management, Calcutta.

J. David Hunger \& Thomas L. Wheelen, Strategic Management and Business Policy, 9th Edition, Pearson Prentice Hall, 2004. Schmitz, H dan Musyek B. 1993. Industrial Districts in Europe: Policy Lessons for Developing Countries. Discussion Paper Institute of Development Studies, (331).

Hill, Charles W.L. dan Jones, Gareth R. 2010. Strategic management theory: An integrated approach. South-Western Cengage Learning, Masonmm
Mohamed dkk. (2009). The Effect of Technology Transfer Factors on Performance: An Empirical Study of Libyan Petroleum Industry, American Journal of Applied Sciences, 6 (9), 1763-1769.

Porter, Michael E. 1990. The Competitive Advantage of Nations. The MacMillan Press Ltd.

Schmitz H dan Nadvi, 1999 Cluster and Industrialisation: an introduction world development, Vol. 27 No. 9 hal 15031514

Sugiyono, (2008), Metode Penelitian Kuantitatif, Kualitatif dan $R \& D$, Penerbit Alfabeta, Bandung.

Tambunan, T.T.H. (2008). Ukuran Daya Saing Koperasi dan UKM. Badan Perencanaan Pembangunan Nasional. 2008.

Tulus TH, Tambunan (2003) UMKM di Indonesia : Jakarta Ghalia Indonesia

Administrasi Kabupaten Sragen (2015) didownload dari http://www.sragenkab. go.id/home.php?menu=20 pada September 2015

Keadaan Tenagakerjaan Daerah Jawa Tengah (2014), Berita Resmi Statistik Provinsi Jawa Tengah No.31/05/33/Th.VIII, 05 Mei 2014

PDRB Kabupaten Sragen (2013), Sragen Dalam Angka (2013) didownload dari http://sragenkab.bps.go.id/pada September 2015

Peraturan Menteri Dalam Negeri Republik Indonesia Nomor 9 Tahun 2014 Tentang Pedoman Pengembangan Produk Unggulan Daerah

Surat Keputusan Menteri Negara Koperasi dan UKM No: 32/Kep/M.KUKM/IV/2002, tanggal 17 April 2002

Sragen Dalam Angka (2013) didownload dari http ://sragenkab.bps.go.id/pada September 2015 
ISSN: 1410-4571

E-ISSN: 2541-2604

Sragen Dalam Angka (2014) didownload UU No. 20 Tahun 2008, www.bi.go.id/id/.../ dari http://sragenkab.bps.go.id/ pada September 2015

uu.../UU20Tahun2008UMKM.pdf 